\title{
KAJIAN TENTANG WANPRESTASI DALAM HUBUNGAN PERJANJIAN
}

\author{
Satiah \\ Fakultas Hukum, Universitas Nahdlatul Wathan, \\ Email: satiahunw@gmail.com \\ Riska Ari Amalia \\ Fakultas Hukum, Universitas Mataram \\ Email: riskaariamalia79@gmail.com
}

\begin{abstract}
Abstrak
Terbitnya perjanjian akan menimbulkan prestasi bagi para pihak. Namun jika salah satu pihak ingkar janji, maka timbul sebuah kebingungan, apakah kasus ini menjadi ranah pidana atau perdata.Adapun rumusan masalah yang diangkat adalah 1) apakah perkara wanprestasi dapat dialihkan menjadi perkara pidana 2) apakah upaya hukum perkara wanprestasi dengan perkara penipuan dapat berjalan dalam waktu yang bersamaan? Tujuan penelitian ini adalah 1) untuk mengetahui apakah hubungan keperdataan dalam wanprestasi dapat beralih menjadi perkara pidana? 2) apakah upaya hukum seseorang yang digugat wanpretasi dan dituntut pidana dapat dilakukan secara bersamaan? Untuk mengkaji permasalahan dalam penelitian ini penulis menggunakan pendekatan perundangundangan(statue approach dan pendekatan konseptual (conceptual approach). Adapun kesimpulan yang dapat ditarik adalah sebagai berikut 1) wanprestasi dan penipuan memiliki unsur yang berbeda sehingga perkara wanprestasi tidak dapat dialihkan menjadi perkara penipuan 2) jika wanprestasi dan penipuan terjadi dalam suatu perkara yang memiliki hubungan hukum maka proses pidana dapat ditangguhkan sampai ada putusan perkara perdata.
\end{abstract}

\section{Kata kunci: Perjanjian; Wanprestasi; Penipuan; Upaya Hukum.}

\begin{abstract}
The issuance of the agreement will lead to achievements for the parties. However, if one of the parties breaks a promise, then a confusion arises as to whether this case is a criminal or civil matter. at the same time? The purpose of this study is 1) to find out whether a civil relationship in a breach of contract can turn into a criminal case? 2) Can the legal action of a person who is sued for breach of contract and charged with a crime be carried out simultaneously? To examine the problems in this study, the author uses a statutory approach (statue approach and conceptual approach). The conclusions that can be drawn are as follows: 1) Default and fraud have different elements so that a default case cannot be transferred to a fraud case. If the default and fraud occur in a case that has a legal relationship, the criminal process can be suspended until there is a civil case decision
\end{abstract}

Keywords: Agreement, default, fraud, legal effort.

\section{A. PENDAHULUAN}

Hukum selalu dinamis mengikuti perkembangan zaman.Baik dalam teori maupun dalam penerapan dalam kehidupan sehari-hari. Sebut saja jual beli online, investasi online, membuat perjanjian yang disepakati via aplikasi online tanpa tanda tangan, menyepakati perjanjian melalui lisan dengan ketentuan diizinkan untuk merekam persetujuan sebagai alat bukti kesepakatan, sampai hanya dengan mengirimkan kartu identitas untuk membuat perjanjian tanpa disaksikan oleh salah satu pihak. Gambaran kasus tersebut merupakan perkembangan perjanjian yang belum diatur dalam Kitab Undang-Undang Hukum Perdata sebagai pedoman utama pengaturan perjanjian. 
Namun berkembangnya perjanjian tidak lantas menghilangkan syarat sahnya perjanjian sebagaimana tercantum pada Pasal 1320 Kitab Undang-Undang Hukum Perdata yang berbunyi empat syarat sahnya suatu perjanjian, yaitu:

Sebuah perjanjian wajib memenuhi syarat sah sebagaimana tercantum dalam Pasal 1320 Kitab Undang-Undang Hukum Perdata. Adapun syarat sah sebuah perjanjian adalah :

1. Sepakat

Artinya perjanjian dibuat berdasarkan kesepakatan para pihak, tanpa paksaan, dan tanpa tipu muslihat.

2. Cakap untuk melakukan perbuatan hukum atau melakukan perikatan

Artinya para pihak yang membuat perjanjian harus berakal (waras), tidak dibawah pengampuan, dan dikatakan dewasa menurut undang-undang.Dalam prakteknya, beberapa kasus perjanjian, khususnya sewa menyewa, para pihak diharuskan tidak memiliki perjanjian yang menimbulkan utang bagi salah satu pihak agar pihak tersebut dapat membuat perjanjian baru.

3. Adanya suatu hal tertentu

Artinya hal yang diperjanjikan harus terang dan jelas agar tidak menimbulkan multitafsir yang bisa menjadi sengketa di kemudian hari.

4. Suatu sebab yang halal

Artinya para pihak tidak boleh membuat perjanjian yang dilarang oleh undang-undang, atau yang bertentangan dengan nilai kesopanan, nilai kesusilaan, dan nilai ketertiban umum. Syarat pertama dan kedua dinamakan syarat subjektif karena berkaitan dengan para pihak, syarat ketiga dan keempat dinamakan objektif karena berkaitan dengan objeknya.Setelah memenuhi syarat perjanjian tadi, para pihak juga harus memenuhi apa yang diperjanjikan (prestasi). Baik tidak dipenuhinya syarat sah maupun prestasi yang timbul akibat perjanjian tersebut pasti akan menimbulkan konsekuensi hukum jika salah satu pihak keberatan.

Hubungan perjanjian dapat menimbulkan konsekuensi secara perdata dan pidana. Seperti pada kasus investasi bodong yang dilakukan oleh Laras Chyntia, selaku pemilik usaha kuliner, Dapoer Emak Caca. Viralnya kasus ini bermula saat korban menyetor modal untuk pengembangan unit bisnis Dapoer Emak Caca di Lombok Tengah, yakni Caca Village'. Korban yang menyetor modal Rp25 juta dijanjikan pengembalian modal dan keuntungan yang totalnya Rp36 juta dalam waktu hanya tiga bulan. ${ }^{2}$ Semenjak kasus mencuat, korban lain terus berdatangan melaporkan hal serupa. Korban investasi bodong Dapoer Emak Caca sendiri berjumlah lebih dari 1 (satu), namun yang diproses pidana hingga tingkat penyidikan, bahkan disidangkan hingga di tingkat pengadilan hanya laporan dari salah satu korban berinisial YD. Para korban tersebut telah berinvestasi di Dapoer Emak Caca sejak tahun 2019. Uang yang diinvestasikan jumlahnya bervariasi, mulai Rp 100 jutaan hingga Rp 250 jutaan. ”Dari 14 orang ini kerugian mereka mencapai Rp 1 miliaran," beber Anton. Hingga kini Pengadilan Negeri Mataram sudah memutus melalui Putusan Pengadilan Negeri Nomor 2/Pid.B/2021/ PN.Mtr, bahwa Laras Chyntia terbukti secara sah dan meyakinkan bersalah melakukan tindak pidana penipuan. Sebagian dari korban menggugat secara perdata, namun antara Penggugat dengan Tergugat telah tercapai kesepakatan saat mediasi sehingga Pengadilan Negeri Mataram mengeluarkan Akta Perdamaian melalui Putusan PN MATARAM Nomor 249/Pdt.G/2020/PN Mtr. kedua putusan tersebut lahir dari asal yang sama, yakni hubungan perjanjian. Dari paparan kasus tersebut terdapat titik singgung antara wanprestasi dengan penipuan sehingga diperlukan analisis lebih lanjut untuk memahami perbedaan dan persamaan .

${ }^{1}$ Dikutip pada tanggal 20 Juni 2021 melalui https://www.suarantb.com/kasus-dugaan-penipuan-investasi-dapoer-emak-caca-diajukan-ke-persidangan/

${ }^{2}$ Ibid. 
Sifat keperdataan suatu hubungan perjanjian dapat menjadi tindakan pidana bilamana unsurunsur penipuan terpenuhi. Sebaliknya, suatu kasus dapat menjadi wanprestasi jika unsur-unsur pidana tidak terpenuhi. Oleh karena itu dibutuhkan pengetahuan dan analisis mendasar agar masyarakat pada umumya, dan aparat penegak hukum pada khususnya dapat memilah suatu kasus dalam hubungan perjanjian. Karena kedua perbuatan hukum tersebut memiliki jalur penyelesaian yang berbeda.Berangkat dari hal inilah penulis tertarik untuk meneliti mengenai Kajian Tentang Wanprestasi Dalam Hubungan Perjanjian : Sebagai Tindakan Perdata Semata?

Berdasarkan uraian singkat latar belakang diatas maka rumusan masalah yang dapat ditarik adalah sebagai berikut :

1. Apakah perkara wanprestasi dapat dialihkan menjadi menjadi perkara pidana penipuan?

2. Apakah gugatan wanprestasi dan tuntutan tindak pidana penipuan dapat berjalan dalam waktu bersamaan?

Dalam prakteknya, karena wanprestasi dan perkara pidana berangkat dari konsepsi yang sama, yaitu ada sesuatu yang diperjanjikan maka penelitian ini menjadi suatu urgensi agar masyarakat, terutama aparat penegak hukum untuk memahami persamaan dan perbedaan wanprestasi dengan penipuan. Oleh karena itu tujuan penelitian adalah untuk menganalisis hal berikut :

1. Untuk mengetahui apakah hubungan keperdataan dalam wanprestasi dapatberalihmenjadi perkara pidana

2. Untuk mengetahui apakah upaya hukum seseorang yang digugat wanpretasi dan dituntut pidana dapat dilakukan secara bersamaan.

\section{B. METODE PENELITIAN}

Jenis penelitian yang digunakan dalam penelitian ini adalah jenis penelitian normatif, yaitu penelitian yang dilakukan dengan mengkaji kaidah atau norma hukum dalam peraturan perundang-undangan serta sumber referensi lain yang terkait dengan penelitian penulis. Untuk mengkaji permasalahan dalam penelitian ini penulis menggunakan pendekatan perundangundangan(statue approach), yakni pendekatan yang dilakukan dengan mengkaji peraturan perundang-undangan dan Pendekatan konseptual (conceptual approach), yaitu pendekatan yang dilakukan dengan mengkaji teori, asas, dan doktrin dalam ilmu hukum yang relevan dengan isu hukum yang diangkat.

\section{PEMBAHASAN}

\section{Analisis Titik Singgung Perkara Wanprestasi dengan Perkara Pidana}

\section{a. Wanprestasi Dalam Suatu Perjanjian}

Sebagai makhluk sosial, interaksi antar manusia di dalam kehidupan sosial wajib terjadi. Pola interaksi ini kemudian diikat oleh suatu norma yang berlaku di masyarakat serta norma hukum. Bentuk interaksi ini dapat melahirkan suatu perbuatan hukum berupa terbentuknya perjanjian. Munir Fuady mengatakan bahwa istilah perjanjian merupakan kesepadanan dari istilah overeenkomst dalam bahasa Belanda atau agreement dalam bahasa Inggris. ${ }^{3}$ Menurut Sutarno perjanjian dibedakan menjadi beberapa jenis yaitu ${ }^{4}$ :

1) Perjanjiantimbal balikadalah perjanjianyang dibuatdengan meletakkan hak dankewajiban kepada kedua belah pihak yang membuat perjanjian. Misalnya perjanjian jual beli Pasal

\footnotetext{
${ }^{3}$ Munir Fuady.(2001). Hukum Kontrak (Dari Sudut Pandang Hukum Bisnis). Bandung: Citra Aditya Bakti, hlm.2

${ }^{4}$ Sutarno.(2003). Aspek-aspek Hukum Perkreditan Pada Bank. Bandung: Alfabeta, hlm.82
} 
1457 Kitab Undang-Undang Hukum Perdata dan perjanjian sewa menyewa Pasal 1548 Kitab Undang-Undang Hukum Perdata. Dalam perjanjian jual beli hak dan kewajiban ada dikedua belah pihak. Pihak penjual berkewajiban menyerahkan barang yang dijual dan berhak mendapat pembayaran dan pihak pembeli berkewajiban membayar dan menerima barangnya;

2) Perjanjian sepihak adalah perjanjian yang dibuat dengan meletakkan kewajiban pada salah satu pihak saja, misalnya perjanjian hibah. Dalam hal ini kewajiban hanya ada pada orang yang menghibahkan yaitu memberikan barang yang dihibahkan sedangkan penerima hibah tidak mempunyai kewajiban apapun. Penerima hibah hanya berhak menerima barang yang dihibahkan tanpa berkewajiban apapun kepada orang yang menghibahkan;

3) Perjanjian dengan percuma adalah perjanjian menurut hukum terjadi keuntungan bagi salah satu pihak saja. Misalnya hibah (schenking) dan pinjam pakai Pasal 1666 Kitab Undang-Undang Hukum Perdata dan 1740 Kitab Undang-Undang Hukum Perdata;

4) Perjanjian konsensual, riil, dan formil. Perjanjian konsensual adalah perjanjian yang dianggap sah apabila telah terjadi kesepakatan antara pihak yang membuat perjanjian. Perjanjian riil adalah perjanjian yang memerlukan kata sepakat tetapi barangnya harus diserahkan. Misalnya penitipan barang Pasal 1741 Kitab Undang-Undang Hukum Perdata. Perjanjian formil adalah perjanjian yang memerlukan kata sepakat tetapi undang-undang mengharuskan perjanjian tersebut harus dibuat dengan bentuk tertentu secara tertulis dengan akta yang dibuat oleh pejabat umum notaris atau PPAT (Pejabat Pembuat Akta Tanah). Misalnya jual beli tanah, undang-undang menentukan akta jual beli harus dibuat dengan akta PPAT, perjanjian perkawinan dibuat dengan akta notaris;

5) Perjanjian bernama atau khusus dan perjanjian tidak bernama. Perjanjian bernama atau khusus adalah perjanjian yang telah diatur dengan ketentuan khusus dalam KUHPerdata buku ke III Bab V sampai dengan Bab XVIII. Misalnya perjanjian jual beli, sewa menyewa, hibah dan lain-lain. Sedangkan perjanjian tidak bernama adalah perjanjian yang berlum ada peraturannya secara khusus di dalam undang-undang. Tentang perjanjian tidak bernama diatur dalam Pasal 1319 Kitab Undang-Undang Hukum Perdata yang menyatakan "semua perjanjian, baik yang mempunyai nama khusus maupun yang tidak dikenal dengan suatu nama tertentu, tunduk pada peraturan umum yang termuat dalam bab ini dan bab lainnya".

Hanya subjek hukum yang dapat melakukan perbuatan hukum.Subjek hukum adalah pemegang hak dan kewajiban menurut hukum atau para pendukung/pemilik hak dan kewajiban. ${ }^{5}$ Hukum kontrak atau hukum perjanjian mengenal 2 (dua) subjek hukum, yakni

1) Manusia.

Ada 2 (dua) alasan yang menyebutkan manusia sebagai subjek hukum, yaitu karena manusia memiliki hak-hak subjektif dan karena memiliki kewenangan hukum yang artinya sudah cakap melakukan perbuatan hukum. ${ }^{6}$

2) Badan hukum

Badan hukum adalah suatu badan yang terdiri dari kumpulan orang yang diberi status persoon oleh hukum sehingga mempunyai hak dan kewajiban. ${ }^{7}$

Manusia dan badan hukum memiliki kesempatan untuk melakukan perjanjian atau kesepakatan.Kesepakatan ini menimbulkan prestasi bagi para pihak yang melakukan perjanjian tersebut sebagaimana yang diatur di dalam Pasal 1338 Kitab Undang-undang Hukum Perdata. Jika isi kesepakatan atau perjanjian tidak dipenuhi, para pihak dapat menempuh jalur litigasi maupun non litigasi sebagai alternatif penyelesaian sengketa.

\footnotetext{
${ }^{5}$ Zainal Asikin.(2012). Pengantar Ilmu Hukum. Jakarta: Raja Grafindo Persada, hlm.33.

${ }^{6} \mathrm{Ibid}, \mathrm{hlm} .34$.

${ }^{7}$ Ibid, hlm. 35.
} 
Jalur litigasi artinya menggugat ke pengadilan yang sesuai dengan kompetensi absolut dan komptensi relatifnya.Jalur non litigasi adalah penyelesaian sengketa di luar pengadilan, artinya upaya tawar-menawar atau kompromi untuk memperoleh jalan keluar yang saling menguntungkan.Para pihak dapat menempuh jalur non litigasi demi tercapainya kesepakatan baru.Bentuk penyelesaian jalur non litigasi adalah sebagai berikut ${ }^{8}$ :

1) Konsultasi , merupakan suatu tindakan yang bersifat personal antara suatu pihak (klien) dengan pihak lain yang merupakan konsultan, yang memberikan pendapatnya atau saran kepada klien tersebut untuk memenuhi keperluan dan kebutuhan klien.

2) Negoisasi,penyelesaiansengketamelaluimusyawarah/perundinganlangsungdiantarapara pihakyang bertikai dengan maksud mencari danmenemukan bentuk-bentuk penyelesaian yang dapat diterima para pihak.Kesepakatan mengenai penyelesaian tersebut selanjutnya harus dituangkan dalam bentuk tertulis yang disetujui oleh para pihak.

3) Mediasi, merupakan penyelesaian sengketa melalui perundingan dengan dibantu oleh pihak luar yang tidak memihak/netral guna memperoleh penyelesaian sengketa yang disepakati oleh para pihak.

4) Konsiliasi berarti perdamaian, penyelesaian sengketa melalui perundingan dengan melibatkan pihak ketiga yang netral (konsisliator) untuk membantu pihak yang berdetikai dalam menemukan bentuk penyelesaian yang disepakati para pihak. Hasil konsilisiasi ini ini harus dibuat secara tertulis dan ditandatangani secara bersama oleh para pihak yang bersengketa, selanjutnya harus didaftarkan di Pengadilan Negeri. Kesepakatan tertulis ini bersifat final dan mengikat para pihak.

Pada prakteknya, para pihak yang bersengketa biasanya mengadakan medasi atau negosiasi sebagai upaya untuk mencari jalan keluar dan kesepakatan sebelum perkara naik ke pengadilan. Dalam penyelesaian perkara non litigasi, kehadiran pihak ketiga yang netral bukan untuk memutuskan sengketa, melainkan para pihak sendirilah yang mengambil keputusan akhir. Hasil penyelesaian sengketa diluar pengadilan dapat dikukuhkan menjadi akta van dading oleh pejabat umum yang berwenang, dalam hal ini notaris sebagai dasar terbitnya kesepakatan baru. Akta van dading memiliki kekuatan mengikat bagi para pihak.

Sesungguhnya perjanjian merupakan hasil dari kesepakatan dua belah pihak, agar pelaksanaanya dapat dinikmati oleh kedua belah pihak. Namun seringkali dalam pelaksanaannya membuat salah satu pihak ataupun kedua belah pihak merasa kurang atau bahkan tidak puas. Perjanjian yang tidak ditepati disebut wanprestasi atau ingkar janji.Wanprestasi hanya dapat terjadi jika didahului oleh perjanjian baik perjanjian tertulis maupun perjanjian lisan. Pengaturan wanprestasi terdapat pada Pasal 1243 Kitab Undang-undang Hukum Perdata, yang menyatakan bahwa:

"penggantian biaya, rugi dan bunga karena tidak dipenuhinya suatu perikatan, barulah mulai diwajibkan, apabila si berutang, setelah dinyatakan lalai memenuhi perikatannya, tetap melalaikannya, atau jika sesuatu yang harus diberikan atau dibuatnya, hanya dapat diberikan atau dibuatnya, hanya dapat diberikan atau dibuat dalam tenggang waktu yang telah dilampaukannya".

Masalah wanprestasi bisa diindentifikasi kemunculan atau terjadinya melalui beberapa parameter sebagai berikut ${ }^{9}$ :

1) Dilihat dari segi sumber terjadinya wanprestasi ;

${ }^{8}$ Dikutip pada tanggal 20 Januari 2021 melalui https://komisiinformasi.bantenprov.go.id/read/arsip-artikel/86/ Perbedaan-Litigasi-Dan-Non-Litigasi.html\#.YAt-jHYzbIU

${ }^{9}$ Putusan Mahkamah Agung No. 932/K/PID/2014, hlm.12-13. 
Wanprestasi timbul dari persetujuan (agreement). Artinya untuk mendalilkan suatu subjek hukum telah melakukan wanprestasi, harus ada lebih dahulu perjanjian antara dua pihak atau lebih sebagaimana ditentukan dalam Pasal 1320 Kitab Undang-Undang Hukum Perdata 2) Dilihat dari segi timbulnya hak menuntut ganti rugi ;

Penuntutan ganti rugi pada wanprestasi diperlukan terlebih dahulu adanya suatu proses, seperti pernyataan lalai dari kreditur (inmorastelling, negligent of expression, inter pellatio, ingeberkestelling).Hal ini penting karena Pasal 1243 Kitab Undang-Undang Hukum Perdata telah menggariskan bahwa "Perikatan ditujukan untuk memberikan sesuatu, untuk berbuat sesuatu atau untuk tidak berbuat sesuatu".

3) Dilihat dari segi tuntutan ganti rugi ;

Ketentuan Pasal 1246 Kitab Undang-Undang Hukum Perdata menyatakan, "biaya, ganti rugi dan bunga, yang boleh dituntut kreditur, terdiri atas kerugian yang telah dideritanya dan keuntungan yang sedianya dapat diperolehnya". Berdasarkan Pasal 1246 Kitab UndangUndang Hukum Perdata tersebut, dalam wanprestasi, perhitungan ganti rugi harus dapat diatur berdasarkan jenis dan jumlahnya secara rinci seperti kerugian kreditur, keuntungan yang akan diperoleh sekiranya perjanjian tersebut dipenuhi dan ganti rugi bunga (interst). Dengan demikian dapat dipahami bahwa ganti rugi dalam wanprestasi (injury damage) yang dapat dituntut harus rinci dan jelas.

Wanprestasi dapat terjadi karena beberapa hal ${ }^{10}$ :

1) tidak melaksanakan apa yang diperjanjikan;

2) melaksanakan yang diperjanjikan tapi tidak sebagaimana mestinya;

3) melaksanakan apa yang diperjanjikan tapi terlambat; atau

4) melakukan sesuatu yang menurut perjanjian tidak boleh dilakukan

Perbuatan wanprestasi dapat terjadi baik karena disengaja maupun tidak disengaja. ${ }^{11}$ Kelalaian melakukan prestasi (wanprestasi) menimbulkan akibat hukum bagi debitur setelah diberikan tenggang waktu, yaitu debitur harus membayar ganti kerugian kepada kreditur jika tenggang waktu yang diberikan oleh kreditur tersebut tidak juga dapat dicapai oleh debitur untuk melaksanakan prestasinya. ${ }^{12}$ Meskipun demikian, debitur bisa saja membela diri dengan alasan ${ }^{13}$

1) Keadaan memaksa (overmacht/force majeure).

2) Kelalaian kreditur sendiri.

3) Kreditur telah melepaskan haknya untuk menuntut ganti rugi.

Berdasarkan uraian diatas bahwa dalam pemenuhan prestasi kedua belah pihak harus mengikuti isi perjanjian. Bila gagal memenuhi prestasi salah satu pihak harus beritikad baik memberitahukan pihak lainnya untuk memberikan permakluman atau kelonggaran. Para pihak juga harus menganalisis sebab akibat pihak lainnya gagal memenuhi prestasi, karena pihak yang mengalami keadaan overmacht tidak perlu membayar ganti rugi. Lain halnya jika prestasi gagal dipenuhi karena kelalaian, sepanjang kelalaian tersebut memenuhi unsur pidana, perkara ingkar janji ini dapat diadili dengan hukum acara pidana.

Aparat penegak hukum wajib memahami secara jelas mengenai batasan wanprestasi dan batasan penipuan. Aparat penegak hukum juga harus menggali keterangan dan mengumpulkan alat bukti dari para pihak sebagai petunjuk untuk melakukan upaya hukum lanjutan. Sebuah perkara wanprestasi pasti diawali dengan adanya itikad baik kedua belah pihak.Dalam setiap

\footnotetext{
${ }^{10}$ Dikutip pada tanggal 12 Januari 2021 melalui https://www.hukumonline.com/klinik/detail/ulasan/cl33/wanprestasi-danpenipuan/\#: :text=Wanprestasi $\% 20$ dapat $\% 20$

Berupa\%3A\%20(i),menurut\%20perjanjian\%20tidak\%20boleh\%20dilakukan.

${ }^{11}$ Ahmadi Miru.(2007). Hukum Kontrak dan Perancangan Kontrak. Jakarta: Rajawali Pers, hlm. 74

${ }^{12}$ Sugirhot Marbun, Perbedaan Antara Wanprestasi Dan Delik Penipuan Dalam Hubungan Perjanjian, USU Law Journal, Vol.3.No.2, Agustus 2015, hlm. 132.

${ }^{13}$ Abdul R. Saliman.(2005). Hukum Bisnis Untuk Perusahaan. Jakarta: Kencana, hlm.47.
} 


\section{[JATISWARA] [Vol. 36 No. 2 Juli 2021]}

pembuatan perjanjian, para pihak pada dasarnya memiliki kebebasan untuk menentukan isi perjanjian, dengan siapa diamembuat perjanjian, namun demikian setiap perjanjian hendaknya selalu dilandaskan pada asas itikad baik, tidak melanggar peraturan perundang-undangan, serta tidak melanggar kepentingan masyarakat. ${ }^{14}$ Keharusan demikian dimaksudkan untuk mewujudkan keadilan para pihak di dalam perjanjian, sehingga tidak terjadi eksploitasi yang kuat terhadap yang lemah. ${ }^{15}$

\section{b. Penipuan Sebagai Perkara Pidana}

Hukum pidana mengenal 2 (dua) subjek hukum, yaitu orang dan badan hukum (korporasi). Setiap subjek hukum berhak melakukan perbuatan hukum yang melahirkan tanggung jawab. Pertanggungjawaban subjek hukum orang atau manusia jelas ditanggung oleh subjek hukum itu sendiri.Adapun subjek hukum korporasi yang terdiri dari sekumpulan orang dapat bertindak atas nama korporasi tersebut.

Sebagaimana dijelaskan pada paragraf selanjutnya, bahwa subjek hukum memiliki legalitas untuk melakukan perbuatan hukum. Salah satunya membuat perjanjian. Dalam pelaksanaan perjanjian tidak menutup kemungkinan salah satu pihak cacat memenuhi prestasi. Kecenderungan penyelesaian suatu perkara dalam hubungan perjanjian, seperti perjanjian hutang piutang, perjanjian fiducia, perjanjian sewa menyewa dengan cara melaporkan ke polisi membuat aparat penegak hukum harus jeli untuk membedakan mana perkara perdata mana perkara pidana. Menurut Ruslan Saleh, tidaklah ada gunanya untuk mempertanggungjawabkan terdakwa atas perbuatannya apabila perbuatannya itu sendiri tidak bersifat melawan hukum, maka lebih lanjut dapat pula dikatakan bahwa terlebih dahulu harus ada kepastian tentang adanya perbuatan pidana, dan kemudian semua unsur-unsur kesalahan harus dihubungkan pula dengan perbuatan pidana yang dilakukan, sehingga untuk adanya kesalahan yang mengakibatkan dipidananya terdakwa maka terdakwa haruslah ${ }^{16}$ :

a. Melakukan perbuatan pidana;

b. Mampu bertanggung jawab;

c. Dengan kesengajaan atau kealpaan, dan

d. Tidak adanya alasan pemaaf.

Terkadang ada pihak yang seakan-akan melakukan wanprestasi padahal sudah masuk unsur penipuan. Untuk menentukan sebuah perkara masuk ke domain perdata atau pidana harus melihat dulu apakah unsur-unsur domain mana yang terpenuhi, apakah domain wanprestasi yang merupakan ranah hukum privat atau domain penipuan yang merupakan ranah hukum publik. Penipuan itu sendiri berarti proses, cara, perbuatan menipu. Kejahatan penipuan itu termasuk materieel delict yang artinya untuk kesempurnaannya harus terjadi akibatnya. ${ }^{17}$ Adapun tindak pidana penipuan diatur pada Pasal 378 Kitab Undang-Undang Hukum Pidana yang berbunyi :

"Barangsiapa dengan maksud untuk menguntungkan diri sendiri atau orang lain secara melawan hukum, dengan memakai nama palsu atau martabat palsu, dengan tipu muslihat, ataupun rangkaian kebohongan, menggerakkan orang lain untuk menyerahkan barang sesuatu kepadanya, atau supaya memberikan hutang maupun menghapuskan piutang”.

Jika dijabarkan unsur penipuan adalah barangsiapa, menguntungkan diri sendiri atau orang lain secara melawan hukum, dengan memakai nama palsu atau martabat palsu, dengan tipu muslihat agar seseorang memberikan utang atau menghapus piutang terhadap lain. Sebuah perbedaan mendasar yang nyata antara wanpretasi dengan tindak pidana penipuan adalah niat.

${ }^{14}$ Luh Nila Winarni, Asas Itikad Baik Sebagai Upaya Perlindungan Konsumen Dalam Perjanjian Pembiayaan, DIH, Jurnal Ilmu Hukum, Vol. 11, No. 21, Pebruari 2015, hlm 3-4.

${ }^{15} \mathrm{Ibid}, \mathrm{hlm} .4$.

${ }^{16}$ Moeljatna.(2007). Asas-Asas Hukum Pidana. Jakarta: Bina Aksara, hlm. 49.

${ }^{17}$ M. Sudrajat Bassar.(2014). dalam Ester Magdalena Robot, dalam karya ilmiah yang berjudul Penerapan Pasal 378 Kuhp Terhadap Kasus Wanprestasi Pada Perjanjian Utang Piutang. Yogyakarta: Universitas Atmajaya, hlm. 6. 
Bilamana perjanjian tersebut dari awal sudah diiringi niat jahat (mens rea) dan tipu muslihat untuk mendapatkan suatu utang atau menghapus piutang maka hal ini masuk unsur tindak pidana penipuan, Sebaliknya jika sebuah perjanjian pada dasarnya diiringi dengan itikad baik namun ada hal yang membuat debitur tidak melaksanakan perjanjian tersebut maka hal ini dapat digolongkan sebagai wanprestasi.Butuh kecermatan dari aparat penegak hukum untuk menggolongkan suatu perbuatan ingkar janji, apakah masuk ke ranah wanprestasi atau tindak pidana penipuan.

Berdasarkan Pasal 1328 Kitab Undang-Undang Hukum Perdata, yang diterjemahkan oleh Subekti dan R. Tjitrosudibio ${ }^{18}$, penipuan merupakan suatu alasan untuk pembatalan perjanjian, apabila tipu muslihat, yang dipakai oleh salah satu pihak, adalah sedemikian rupa hingga terang dan nyata bahwa pihak yang lain tidak telah membuat perikatan itu jika tidak dilakukan tipu muslihat tersebut. Penipuan tidak dipersangkakan, tetapi harus dibuktikan. ${ }^{19}$ Penipuan juga memiliki unsur objektif dan unsur subjektif. Unsur objektif yang berkaitan dengan objek perjanjiannya, yaitu ${ }^{20}$ :

1) Perbuatan menggerakkan (bewegen)

2) Yang digerakkan adalah orang

Sedangkan unsur subjektifnya adalah :

1) Maksud untuk menguntungkan diri sendiri atau orang lain

2) Dengan melawan hukum.

Unsursubjektif meliputisubjek dan adanya unsurkesalahan. Sedangkan yang termasuk unsur objektif adalah perbuatannya bersifat melawan hukum, tindakan yang dilarang atau diharuskan oleh undang-undang/perundangan dan terhadap pelanggarnya diancam pidana, dan dilakukan dalam waktu, tempat dan keadaan tertentu. ${ }^{r}$ Unsur objektif dan unsur subjektif tersebut harus terpenuhi untuk menentukan adanya tindak pidana.

Dalam perjanjian seseorang atau para pihak dibebaskan dari ganti rugi apabila mengalami overmacht. Apabila dalam sebuah perjanjian salah satu pihak memalsukan keadaan overmacht agar tidak memenuhi prestasi maka pihak yang dirugikan dapat melapor ke kantor polisi terdekat dengan membawa bukti permulaan terhadap sangkaan tindak pidana penipuan. Namun jika perjanjian yang dijadikan dasar laporan aduan penipuan,karena salah satu pihak ingkar janji, sepanjang tidak ada pemalsuan dan tidak ada tipu muslihat untuk memenuhi prestasi, maka jalur yang dipilih oleh para pihak adalah dengan mengajukan gugatan perdata.

\section{c. Titik Singgung Wanprestasi dengan Penipuan}

Seringkali pelaku ingkar janji menghindari jerat pidana dengan berlindung melalui sifat hukum perdata, yang tidak memberikan hukuman badan selayaknya hukum pidana.Untuk menentukan perbuatan ingkar janji tersebut perbuatan wanprestasi atau tindak pidana penipuan adalah pertama keabsahan perjanjian harus diperiksa, apakah perjanjian tersebut benar ada dan sudah memenuhi syarat sah berdasarkan Pasal 1320 Kitab Undang-Undang Hukum Perdata atau tidak. Atau jika perjanjian tersebut dituangkan dalam akta autentik apakah akta tersebut memenuhi syarat sebagaimana diatur dalam Undang-Undang Nomor 30 Tahun 2004 tentang Jabatan Notaris.Kemudian yang dilihat adalah apakah perbuatan ingkar janji tersebut dilakukan secara sengaja atau memang dilakukan karena keadaan terpaksa.

${ }^{18}$ Dikutip pada tanggal 28 Januari 2021 melalui nik/detail/ulasan/lt58726763cfdcc/bisakah-kasus-penipuan-diproses-hukum-pidana-dan-perdata-secara-bersamaan/

${ }^{19}$ Ibid.

${ }^{20}$ Azhari AR, Prestasi Dan Penipuan Dari Suatu Perjanjian, Jurnal Hukum Kaidah Media Komunikasi Dan Informasi Hukum Dan Masyarakat, Vol. 19, No. 3, 2020, hlm. 488-491

${ }^{21}$ Dikutip pada tanggal 20 Juni 2021 melalui https://www.hukumonline.com/klinik/detail/ulasan/lt5236f79d8e4b4/mengenal-unsur-tindak-pidana-dan-syarat-pemenuhannya/ 
Parameter pembeda wanprestasi dengan tindak pidana penipuan adalah pada wanprestasi dilihat dari adanya itikad baik para pihak, sedangkan pada tindak pidana penipuan dilatarbelakangi niat jahat (mens rea) dalam memiliki suatu benda (barang) milik orang lain serta dengan melihat apakah ada unsur kesengajaan untuk tidak menunaikan prestasinya. Perbuatan wanprestasi murni dan tindak pidana penipuan juga memiliki penyelesaian berbeda, yaitu perkara wanprestasi diselesaikan melalui gugatan perdata yang jika gugatan dimenangkan maka penyelesaiannya berupa pengembalian hak-hak penggugat atau tergugat, tergantung keyakinan hakim.Sedangkan tindak pidana penipuan diawali dengan laporan ke pejabat yang berwenang (polisi), dilakukan penuntutan oleh jaksa penuntut umum, dan diputus oleh hakim.Hukumannya pun berupa hukuman badan. Sejauh salah satu pihak memenuhi unsur penipuan, meskipun pihak tersebut sudah melakukan prestasi saat proses penyidikan berjalan, hal ini tidak menghapuskan unsur pidana dari perbuatannya. Artinya pihak tersebut harus mempertanggungjawabkan perbuatannya secara pidana, dengan hukuman penjara untuk memberikan efek jera. Sejauh wanprestasi tersebut dilakukan dengan keadaan terpaksa dan dapat dibuktikan, kelalaian kreditur sendiri., kreditur telah melepaskan haknya untuk menuntut ganti rugi, maka perbuatan tersebut tidak dapat dibawa ke ranah pidana, dan menjadi ranah perdata. Namun jika perjanjian tersebut dilakukan karena sudah ada niat, dan adanya usaha untuk memalsukan isi perjanjian tersebut atau keadaan pihak tersebut maka perkara ingkar janji dapat masuk ke ranah pidana dengan dugaan penipuan.

Meski memiliki kemiripan, wanprestasi dan penipuan memiliki unsur masing-masing.Hal ini yang menjadikan bahwa perkara wanprestasi tidak dapat dialihkan menjadi perkara pidana.

\section{Upaya Hukum Perkara Wanprestasi dan Penipuan}

\section{a. Perbedaan Alur Upaya Hukum Wanprestasi dengan Tindak Pidana Penipuan}

Wanprestasi dapat terjadi pada satu pihak, dan dapat terjadi pada banyak pihak.peralihan sebuah perkara wanprestasi menjadi perkara penipuan tergantung pada tahap pembuktian. Jika perbuatan ingkar janji digugat sebagai perkara perdata padahal tidak memenuhi unsur wanprestasi, sebaliknya, ingkar janji terjadi karena adanya tipu muslihat, dapat mengakibatkan gugatan kabur (obscuur libel) sehingga gugatan tidak dapat diterima (niet ontvankelijke verklaard).Yahya Harahap menjelaskan ada beberapa sebab yang membuat gugatan tidak dapat diterima, yaitu ${ }^{22}$ :

1) Gugatan yang ditandatangani kuasa berdasarkan surat kuasa yang tidak memenuhi syarat yang digariskan Pasal 123 ayat (1) HIR;

2) Gugatan tidak memiliki dasar hukum;

3) Gugatan error in persona dalam bentuk diskualifikasi atau plurium litis consortium;

4) Gugatan mengandung cacat obscuur libel, ne bis in idem, atau melanggar yurisdiksi (kompetensi) absolut atau relatif.

Perbuatan ingkar janji yang digugat secara perdata dengan dituntut secara pidana memiliki alur proses hukum yang berbeda. Khusus dalam perkara wanprestasi, salah satu pihak yang merasa dirugikan dapat terlebih dahulu melayangkan somasi kepada pihak lainnya sebagai bentuk teguran bahwa pihak tersebut lalai menjalankan prestasinya.Somasi berbentuk tertulis, yang di dalamnya memuat hal-hal seperti : 1) Kop surat lembaga (bila pakai instansi); 2) Identitas yang dituju; 3) Identitas pengirim somasi (bisa perorangan atau intansi; 4) Duduknya perkara; 5) Hal-hal yang dituntut (yang diinginkan si berpiutang terhadap si berutang); 6) Jarak waktu yang yang diberikan kepada si berutang untuk memenuhi prestasi; 7) Upaya hukum lanjutan yang akan ditempuh apabila si berutang tidak memenuhi prestasi yang dituntut; 8)

${ }^{22}$ Dikutip pada tanggal 28 Januari 2020 melalui https://www.hukumonline.com/klinik/detail/ulasan/lt54f3260e923fb/arti-putusan-niet-ontvankelijke-verklaard-no/ 
Tandatangan pengirim somasi. ${ }^{23}$ Somasi dikirimkan sebanyak 3 (tiga) kali dengan rentang waktu tertentu.

Sebelum gugatan didaftarkan, para pihak dapat melakukan penyelesaian secara kekeluargaan atau non litigasi.Pertemuan ini wajib dibuatkan berita acara untuk menjadi bukti bahwa para pihak telah beritikad baik untu menyelesaikan perkara.Jika para pihak sepakat berdamai dapat dibuatkan akta van dading di hadapan notaris.Jika tidak ada titik temu pada jalur ini para pihak dapat menempuh jalur litigasi.Alur perkara perdata dimulai dengan masuknya gugatan oleh penggugat, kepada tergugat.Baik penggugat maupun tergugat dapat berjumlah lebih dari satu. Sejak masuknya gugatan, hakim akan menawarkan mediasi kepada kedua belah pihak, jika para pihak sepakat berdamai maka hakim akan membuatkan akta van dading. Jika ternyata terjadi deadlockatau buntu maka proses persidangan akan kembali berjalan, dengan surat menyurat antara penggugat dengan tergugat. Sampai akhirnya di tahap pembuktian, penggugat harus membuktikan gugatannya, dan tergugat pun harus membuktikan eksepsinya. Gugatan ini dapat dialamatkan kepada tergugat dan turut tergugat.Selanjutnya majelis hakim yang akan menilai apakah bukti yang diajukan pihak penggugat dan tergugat berkesesuaian dengan perkara tersebut. Majelis hakim juga akan menilai bagaimana kekuatan bukti yang diajukan. Apakah saksi yang diajukan pihak penggugat dan pihak tergugat saksi de audituatau saksi fakta. Pembuktian adalah bagian terpenting saat proses persidangan karena bukti yang diajukan akan mempengaruhi putusan akhir yang akan diputus dan dibaca oleh majelis hakim. Adapun isi putusan akhir dapat berupa :

1) Gugatan dikabulkan

Gugatan dikabulkan ini dapat berupa dikabulkan seluruhnya dapat berupa dikabulkan sebagian.

2) Gugatan tidak dapat diterima

Majelis hakim akan mengeluarkan putusan bahwa gugatan tidak dapat diterima karena majelis hakim menganggap bahwa gugatan tersebut cacat formil.

3) Gugatan ditolak

Gugatan ditolak oleh majelis hakim jika gugatan tersebut cacat materil, artinya penggugat gagal membuktikan gugatannya.

Hasil dari putusan akhir dapat membebani salah satu pihak, baik penggugat atau tergugat untuk memenuhi prestasi dan mengganti biaya kerugian baik materiil maupun immateriil atas wanprestasi yang dilakukannya. Penggugat dan tergugat diberikan hak yang sama untuk menerima atau mempertimbangkan untuk mengajukan upaya hukum lagi terhadap putusan tersebut dengan diberikannya jangka waktu untuk berpikir kembali.

Mekanisme penyelesaian perbuatan tindak pidana penipuan berbeda dengan wanprestasi. Setiap perbuatan yang terindikasi adanya perbuatan pidana wajib didahului oleh penyelidikan dan penyidikan terlebih dahulu oleh pejabat yang berwenang. Untuk tindak pidana umum seperti penipuan maka pejabat yang berwenang menyelidiki dan menyidik adalah polisi. Penyelidikan adalah serangkaian tindakan untuk menentukan adanya suatu pebuatan pidana. Penyidikan adalah serangkaian tindakan untuk menentukan tersangka dan motif perbuatan pidana tersebut. Selain itu polisi juga harus mencari tahu apakah tindak pidana ini dilakukan sendiri atau secara bersama-sama, atau dibantu oleh orang lain. Ketika kedua langkah ini rampung, berkas akan dikirimkanoleh polisi ke penuntut umum untuk diperiksa dan dilakukan penuntutan. Selanjutnya penuntut umum yang bersidang untuk membuktikan tindak pidana tersebut.Sistem pembuktian dalam hukum pidana formil menempatkan Jaksa Penuntut Umum sebagai pihak yang wajib membuktikan suatu perbuatan yang dikategorikan sebagai tindak

${ }^{23}$ Dikutip pada tanggal 30 Januari 2021 melalui http://hukum.up45.ac.id/pentingnya-somasi-dalam-penanganan-masalah-yang-timbul-dalam-perjanjian/ 
pidana. ${ }^{24}$ Pun advokat sebagai penasehat hukum terdakwa akan mendampingi terdakwa dan memastikan bahwa hak-hak terdakwa tidak ada yang dirugikan. Selanjutnya hakim yang memutus apakah terdakwa bersalah atau tidak terbukti melakukan tindak pidana. Tindak pidana penipuan merupakan delik formil-materiil.Diperlukan pembuktian bahwa korban penipuan dalam menyerahkan suatu benda dan seterusnya kepada pelaku tersebut, harus benar-benar kausaliteit (berhubungan dan disebabkan oleh cara-cara pelaku penipuan) sebagaimana tertulis dalam Pasal 378 Kitab Undang-Undang Hukum Pidana.Ketika putusan akhir, jaksa penuntut umum dan terdakwa diberikan waktu untuk menerima atau mengajukan upaya hukum lagi.

Dalam perbuatan pidana penipuan dengan korban tunggal maupun terhadap korban massal memiliki mekanisme hukum acara yang sama. Berdasarkan Pasal 142 Kitab Undang-Undang Hukum Acara Pidana, jaksa penuntut umum diperbolehkan mengambil kebijaksanaan untuk memecah berkas jika menerima berkas tindak pidana yang dilakukan oleh beberapa terdakwa serta menuntut masing-masing terdakwa tersebut. Hal ini dimaksudkan agar masing-masing terdakwa dapat menjadi saksi untuk terdakwa lainnya. Terkait dengan penipuan dengan korban massal maka setiap orang berhak melaporkan dugaan penipuan secara terpisah maupun sendirisendiri.hal itu merupakan hak hukum setiap orang. Namun apabila laporan yang dilakukan secara terpisah terhadap pelaku yang sama, dalam dugaan tindak pidana yang sama, dan yang dilakukan pada suatu waktu dan tempat yang sama ini dimaksudkan agar pelaku mendapatkan hukuman yang terpisah dan berulang-ulang sehingga bisa diakumulasikan, maka hal tersebut tidak dibenarkan secara hukum. ${ }^{25}$

\section{b. Upaya Hukum Terhadap Perbuatan Wanprestasi Dan Penipuan Yang Dilakukan Secara Bersamaan}

Kejahatan terhadap harta benda termasuk kejahatan yang banyak terjadi di masyarakat. Unsur-unsur khas dari masing-masing tindak pidana terhadap harta benda ialah ${ }^{26}$ :

1) dari pencurian (diefstal) : mengambil barang orang lain untuk memilikinya;

2) dari pemerasan (afpersing) : memaksa orang lain dengan kekerasan untuk memberikan sesuatu;

3) dari penipuan (oplichting) : membujuk orang lain dengan tipu muslihat untuk memberi sesuatu;

4) dari penggelapan (verduistering) : memiliki barang yang sudah ada ditangannya (zich to eigenen);

5) dari penadahan : menerima atau memperlakukan barang yang diperoleh orang lain.

Tak jarang kejahatan terhadap harta tidak terbukti karena ternyata masuk ke ranah perdata seperti dugaan penipuan, setelah ditelusuri ternyata perbuatan tersebut merupakan wanprestasi.

Pada kasus korban tunggal, pemisah antara penipuan dan wanprestasi begitu jelas. Suatu tindak pidana penipuanteridentifikasi sejak tahap penyelidikan. Namun tak jarang saat proses pembuktian di persidangan, ternyata tindak pidana yang didalilkan ternyata tidak dapat dibuktikan sehingga hakim mendalilkan bahwa perkara tersebut bukan tindak pidana penipuan melainkan wanprestasi. Putusan perkara pidana ini dapat dijadikan dasar oleh korban untuk melayangkan gugatan terhadap tersangka, yang sekarang statusnya adalah tergugat.Karena sifat keperdataan hanya mengatur hubungan orang perorangan, maka hukumannya sebatas ganti rugi dan uang paksa untuk setiap hari keterlambatan pelaksanaan putusan yang sudah inkracht.Pada kasus korban massal, polisi harus memilah mana yang merupakan perbuatan

\footnotetext{
${ }^{24}$ Nurhayani, Pembuktian Terbalik Dalam Pemeriksaan Tindak Pidana Korupsi Di Indonesia, Jurnal IUS, Vol III, No. 7 , April 2015, hlm, 98.

${ }^{25}$ Dikutip pada tanggal 30 Januari 2021, melalui https:/www.hukumonline.com/klinik/detail/ulasan/lt5a8f0693d0dd6/bisakah-hukuman-diakumulasi-berdasarkan-banyaknya-korban-yang-melapor/

${ }^{26}$ Tim Penyusun Modul Badan Diklat Kejaksaan R.I.(2019). Modul Delik Tertentu Dalam KUHP, Badan Pendidikan Dan Pelatihan Kejaksaan Republik Indonesia. Jakarta, hlm. 6.
} 
penipuan dengan waprestasi. Pada prakteknya polisi akan mendata siapa saja korban penipuan tersebut karena seorang pelaku penipuan tidak dapat dituntut berkali-kali atas kasus yang sama meskipun penipuannya terhadap orang yang berbeda(nebis in idem).

Terhadap wanprestasi sudah jelas bahwa pihak yang kalah tidak akan mendapat hukuman badan, akan tetapi bentuknya ganti rugi. Hal ini menyisakan pertanyaan pada penyelesaian kasus tindak pidana penipuan.Dapatkah korban menuntut ganti rugi terhadap perbuatan ingkar janji yang memenuhi unsur pidana penipuan? Ternyata Undang-Undang Nomor 8 Tahun 1981 sudah memberi peluang melalui Pasal 98 ayat (1), yang tertulis :

Jika suatu perbuatan yang menjadi dasar dakwaan di dalam suatu pemeriksaan perkara pidana oleh pengadilan negeri menimbulkan kerugian bagi orang lain, maka hakim ketua sidang atas permintaan orang itu dapat menetapkan untuk menggabungkan perkara gugatan ganti kerugian kepada perkara pidana itu."

Adapun hal-hal yang perlu diperhatikan dalam implementasi Pasal 98 Kitab UndangUndang Hukum Pidana adalah sebagai berikut ${ }^{27}$ :

1) Restitusi Dan Kompensasi, kedua istilah ini sering dipertukarkan (interchangable). Kompensansi timbul dari permintaan korban, dan dibayaroleh masyarakat atau merupakan bentuk pertanggung jawaban masyarakat/negara (the responsibility of the society), karena negara adalah fundamental bahwa setiap warga negara seharusnya memilikibentukjaminan terhadap resiko kejahatan, sebagai bentuk solidaritas sosial.

2) Restitusi bersifat pidana (penal in characte), timbul dari putusan pengadilan pidana, dan dibayar oleh terpidana atau merupakan wujud pertanggung jawaban terpidana (the responsibility of the offender)

3) Kompensasi yang bersifat perdata, diberikan melalui proses pidana dan di dukung oleh sumber-sumber penghasilan negara. Kompensasi ini tidak memiliki aspek pidana apapun, tetapi negara yang memberikan kompensasi sebagai bentuk bahwa negara telah gagal memberikan keamanan bagi rakyatnya.

4) Kompensasi yang bersifat netral, diberikan melalui prosedur khusus. Sistem ini diterapkan dalam hal korban memerlukan ganti rugi, sedangkan si pelaku dalam keadaan bangkrut dan tidak dapat memenuhi tuntutan ganti rugi kepada korban.

Melalui Pasal 98 ayat (1) negara berupaya memberikan perlindungan hukum terhadap hakhak korban kejahatan terhadap benda secara umumnya, namun implementasi dari pasal ini syarat akan masalah. Salah satunya jika hakim menolak untuk memberikan ketetapan penggabungan perkara pidana dengan perdata lalu bagaimana permintaan ganti rugi terhadap hak-hak korban. Walaupun hukum pidana sudah mengekang kebebasan korban selama beberapa waktu tetapi hal ini tidak lantas memulihkan hak-hak korban terhadap harta bendanya.

Adapun terhadap korban massal yang sebagian perbuatan terhadap korban memenuhi unsur penipuan, dan sebagiannya lagi memenuhi unsur wanprestasi, maka jika kedua proses hukum berjalan, proses pidana ditangguhkan sampai proses perdata mendapat kekuatan hukum tetap, hal ini sesuai dengan Peraturan Mahkamah Agung Nomor 1 Tahun 1956, Surat Edaran Mahkamah Agung Republik Indonesia Nomor 4 Tahun 1980, dan surat panduan penuntutan yang dikeluarkan oleh Kepala Kejaksaan Agung Nomor B/230/E/EJP/01/2013 tertanggal 22 Januari 2013. Seyogyanya penyidik tidak akan melanjutkan proses penyidikan sampai proses hukum secara perdata selesai jika kasus tersebut memiliki hubungan hukum secara pidana dan perdata.

${ }^{27}$ Sujoko.(2008). Implementasi Tuntutan Ganti Kerugian Dalam Pasal 98 Kuhap Terhadap Tindak Pidana Pemerkosaan Di Wilayah Hukum Semarang. Semarang: Tesis Universitas Diponegoro, hlm. 122. 


\section{KESIMPULAN}

Berdasarkan pemaparan diatas maka kesimpulannya adalah Karena wanprestasi dan penipuan memiliki unsur masing-masing, maka subjek hukum tidak dapat dikenakan keduanya oleh korban tunggal. Sehingga perkara wanprestasi tidak dapat dialihkan menjadi perkara pidana, khususnya penipuan sejauh perbuatan tersebut tidak memenuhi unsur penipuan, serta untuk korban tunggal, perkara wanprestasi dan penipuan dapat digabungkan menjadi satu perkara berdasarkan Pasal 98 ayat (1) Kitab Undang-Undang Hukum Acara Pidana. Tetapi perbuataningkar janji terhadap korban massal, jika sebagian korban merupakan korban tindakan wanprestasi, dan sebagian lagi merupaan korban penipuan, maka jika ada korban atau pihak yang menggugat wanprestasi, proses penyelidikan ataupun penyidikan ditangguhkan.

\section{DAFTAR PUSTAKA}

\section{Buku}

Abdul R. Saliman.(2005). Hukum Bisnis Untuk Perusahaan. Jakarta: Kencana.

Ahmadi Miru.(2007). Hukum Kontrak dan Perancangan Kontrak, Jakarta: Rajawali Pers.

Munir Fuady. (2001).Hukum Kontrak (Dari Sudut Pandang Hukum Bisnis). Bandung: Citra Aditya Bakti.

Sutarno. (2003). Aspek-aspek Hukum Perkreditan Pada Bank. Bandung: Alfabeta.

Tim Penyusun Modul Badan Diklat Kejaksaan R.I., Modul Delik Tertentu Dalam KUHP, Badan Pendidikan Dan Pelatihan Kejaksaan Republik Indonesia Jakarta, 2019.

Zainal Asikin.(2012). Pengantar Ilmu Hukum. Jakarta: Raja Grafindo Persada.

\section{Karya Ilmiah}

Azhari AR, Prestasi Dan Penipuan Dari Suatu Perjanjian, Jurnal Hukum Kaidah Media Komunikasi Dan Informasi Hukum Dan Masyarakat, Vol. 19, No. 3, 2020.

Christin Sasauw, Tinjauan Yuridis Tentang Kekuatan Mengikat Suatu Akta Notaris, Lex Privatum, Vol. III No.1 (Januari-Maret 2015).

Ida Bagus Paramaningrat Manuaba I Wayan Parsa I Gusti Ketut Ariawan, Prinsip KehatiHatian Notaris Dalam Membuat Akta Autentik, Acta Comitas, No. 1 (2017-2018).

Luh Nila Winarni, Asas Itikad Baik Sebagai Upaya Perlindungan Konsumen Dalam Perjanjian Pembiayaan, DIH, Jurnal Ilmu Hukum, Vol. 11, No. 21, Pebruari 2015.

M. Sudrajat Bassar, dalam Ester Magdalena Robot, dalam karya ilmiah yang berjudul Penerapan Pasal 378 Kuhp Terhadap Kasus Wanprestasi Pada Perjanjian Utang Piutang, Universitas Atmajaya, Yogyakarta, 2014.

Moeljatna, Asas-Asas Hukum Pidana, Bina Aksara. Jakarta, 2007.

Nurhayani, Pembuktian Terbalik Dalam Pemeriksaan Tindak Pidana Korupsi Di Indonesia, Jurnal IUS, Vol III, No. 7, April 2015

Sugirhot Marbun, Perbedaan Antara Wanprestasi Dan Delik Penipuan Dalam Hubungan Perjanjian, USU Law Journal, Vol.3.No.2, Agustus 2015.

Sujoko, Implementasi Tuntutan Ganti Kerugian Dalam Pasal 98 Kuhap Terhadap Tindak 
Pidana Pemerkosaan Di Wilayah Hukum Semarang, Tesis Universitas Diponegoro, Semarang, 2008.

\section{Putusan Pengadilan}

Putusan Mahkamah Agung No. 932/K/PID/2014.

\section{Situs Online}

https://komisiinformasi.bantenprov.go.id/read/arsip-artikel/86/Perbedaan-Litigasi-Dan-NonLitigasi.html\#.YAt-jHYzbIU

https://www.hukumonline.com/klinik/detail/ulasan/c133/wanprestasidanpenipuan/\#: :text=Wanprestasi\%20dapat\%20berupa\%3A\%20(i),menurut\%20 perjanjian\%20tidak\%20boleh\%20dilakukan.

https://www.hukumonline.com/berita/baca/lt5cc6c36e5eb56/kenali-teori-ini-agar-efektif

menindak-kejahatan-korporasi?page=2nik/detail/ulasan/lt58726763cfdcc/bisakah-kasuspenipuan-diproses-hukum-pidana-dan-perdata-secara-bersamaan/

https://www.hukumonline.com/klinik/detail/ulasan/lt54f3260e923fb/arti-putusan-nietontvankelijke-verklaard-no/

http://hukum.up45.ac.id/pentingnya-somasi-dalam-penanganan-masalah-yang-timbul-dalamperjanjian/

https://www.hukumonline.com/klinik/detail/ulasan/lt5a8f0693d0dd6/bisakah-hukumandiakumulasi-berdasarkan-banyaknya-korban-yang-melapor/

https://www.hukumonline.com/klinik/detail/ulasan/1t5236f79d8e4b4/mengenal-unsur-tindakpidana-dan-syarat-pemenuhannya/ 